Litinfinite Journal

ISSN: 2582-0400 [Online]

CODEN: LITIBR

Vol-2, Issue-1 ( $2^{\text {nd }}$ July, 2020)

Page No: $11-16$

DOI: 10.47365/litinfinite.2.1.2020.11-16

Section: Article

\title{
Chasing the Jeepney: Marxist Reading in Ruth Elynia S. Mabanglo's PaghabolngDyip
}

\author{
Ariel Ursolon Bosque \\ Instruktor (Instructor) \\ Kagawaran ng Filipino, Kolehiyo ng Edukasyon \\ Unit Head \\ Rewards and Recognition, Human Resource Development Center \\ Rizal Technological University \\ Mandaluyong, Philippines \\ Mail I.d.: arielbosquee@gmail.com
}

\begin{abstract}
This paper critiques the poem Paghabol ng Dyip of Ruth Elynia S. Mabanglo. It discusses the facets outside the feminist theme of the poem. It considers manifestations of socio-politico-economic dimensions through the reading using Marxism as the literary lens in the criticism and reinforced by the three factors in assessing through this approach. The study reveals the struggles of the robotic-like life of the workers in the service economy and the dehumanizing exploitation by the manipulative capitalists as portrayed by the suffering of the persona. The mechanized actions are brought by the goal of fulfilling the expectation of other people as they are transforming as commodities that are becoming eroticized objects. The forces of politics in the society, as seen in the poem, are motivated in the exhibition of freedom as the persona has agonized in his/ her enclosures - poverty and exploitation. Depiction of emotional exhaustion was also present. The dependence on the dominant pursuing capitalistic hegemony is added to the prevailing bourgeois values. Mabanglo uses particular metaphors for the capitalization of bigger forces in the community regardless of the gender using Bernardo Carpio - a local fictional character - to embody the workforce. The jeepney represents the persona's chase in life.
\end{abstract}

Keywords: Marxism Approach, poverty, exploitation, service economy, ideology

In March 2020, I was able to participate in the Undergraduate and Graduate Conference on Literary, Cultural, and Performance Studies conducted by the Department of Literature of De La Salle University-Manila, Philippines. One of the papers presented was $S a$ Umaga at sa Gabi: Ang Salungatan sa Paglikha ng Babaeng Persona sa "Paghabol ng Dyip" ni Ruth Elynia Mabanglo at "Time In" ni Yeng Constantino by Deidre Morales, it discusses the politics in feminist writing through cultural materialism.

The first mentioned literature, PaghabolngDyip, was written by a known feminist scholar and poet - Ruth Elynia S. Mabanglo - who was regarded for her progressive wit in poetry and writing in a male-dominated literary stream in the Philippines in the 70s. Her writing enquires into the pressing societal issues, especially the experiences and oppression of women. Despite her display of masculine literary prowess (Tadiar, 113), she was able to reinforce feminist writing. Tadiar added that: 
Litinfinite Journal

ISSN: 2582-0400 [Online]

CODEN: LITIBR

Vol-2, Issue-1 (2 $\left.{ }^{\text {nd }} J u l y, 2020\right)$

Page No: $11-16$

DOI: 10.47365/litinfinite.2.1.2020.11-16

Section: Article

Mabanglo'sinclusion in the modernist movements in the 1960s signifies her achievement in poetry of what [Virgilio] Almario himself had defined as the masculine ideals of self-control, boldness of verse, fearless rebellion against convention and tradition and the power to confront and express the experience the truth of contemporary crisis (Tadiar, 113)

Critics are questioning her far-reaching feminist theme, but, Mabanglo's writing is undeniably redoubtable in analyzing the struggles of the society and mass through her poesy. Her kind of writing is an evidence of the power of the mass.

The nucleus of the discussion of Morales focuses on the development of women's experiences from the critiqued literary pieces; however, in veering the lens, Paghabol (abbreviated henceforth) possesses an opportunity for a new wave of reading.

Panda (on Adesina 4) identified three factors that can be considered in reading the literature through the Marxist approach, these are as follows:

1. There is a class history and class struggle in a literary text.

2. Struggle is there, [it] means there is a domination and oppression. And in that, someone has to win, and someone has to defeat. It belongs to a particular society and culture

3. There are influential factors like political motives behind the production of a text (the text is for whom? And why?)

This kind of paradigm shows focuses on Marxism as it progresses in "ideas are weapons in a field of struggle" (Eagleton, 234). Experiences projected in literature can be used to reflect the asserting reality of the society, and to discuss the motive of human actions especially the dominant. The emergence of this kind of criticism in society can communicate opportunities in reading the ideological conditions of the cultural texts in a capitalist society.

\section{The Class History and Struggle}

Jeepney or jeep/dyip is a common public utility vehicle in the Philippines. It has given experiences to the Filipinos - especially the working class - in travelling. This metaphor shows the comparison of the life of persona and the jeepney. Same as the vehicle, people need to travel. The destination is a staple, but travel is the process.

The writing of Paghabol was the manifestation of Mabanglo's exposition to the workers' negative experiences in their workplaces. It agrees to the analysis of Hernando; she mentions that "nakongretisa niya ang tila awtomatikong pagsunod ng katawan sa batas ng paggawa at pangangapital nito." ("Mabanglo concretized the automatic adherence of the body to the rules of work and its capitalization."; 39)

Paghabol can be noted as a communication on the oppression expressed through the daily struggles that seemed to become customary to the persona - much like the chasing of the jeepney every day. It explains how the poem became a production ideology due to the history of the hegemonic dominant and struggling oppressed. Understanding the existence of 
Litinfinite Journal

ISSN: 2582-0400 [Online]

CODEN: LITIBR

Vol-2, Issue-1 ( $2^{\text {nd }}$ July, 2020)

Page No: $11-16$

DOI: 10.47365/litinfinite.2.1.2020.11-16

Section: Article

hegemony is influenced by the detailed analyses of cultural, socio-economic, and political implications. The poem conveys:

\section{Muli'ysinusianakongtilarelos \\ ng umaga -(Mabanglo, 396)}

Mabanglo's use of muli/again indicates that this kind of circumstance is prevalent and that the persona has accumulated experiences from these situations. The simile of portraying as a watch defines manipulation. The persona becomes a machinery of bigger and stronger forces. This situation is becoming relative substantially in issues such as workforce. A redeclaration of this statement was indicated in Line 15, an attestation of the persona's loss of liberty to control his/her life. Therefore, it reinforces the reality of the service economy. Furthermore, the time determined as umaga/morning explains that the day of the persona starts in the morning.

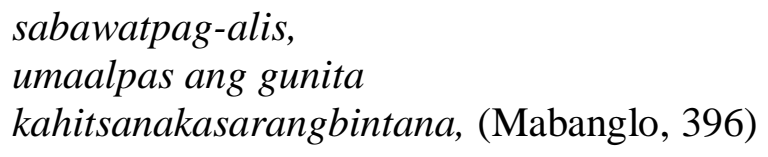

These lines are reminders of the struggles held by the fate of the persona. This interpretation becomes significant because of the experiences of Mabanglo with the mass, and her participation in the movements. She has developed a mental image in her poesy on how the persona battles life.

This positioning is a presentation of society as a literary text. It necessitates the organization of intellectual discourse through critical capabilities.

\section{The Domination and Oppression}

Understanding the political positions in this criticism is essential. Althusser defined the use of analyzing the ideological state apparatus, and he added that "the primary argument of capitalist class struggle consists, at this level, in the ideological imposture about the 'purely technical' division, organization, and management of labour" (Althusser, 36). It reinforces the understanding in critiquing the scheme used by the regulating systems in honing its constituents through the use of ideologies, and it is, indeed, a requisite in discerning the way society generates people on their image. Mabanglo writes:

\section{kamay at paang humaplit (Mabanglo, 396)}

The verse demonstrates the mechanized actions of the persona to the point that the body immediately recognizes since it is routinary or memorized. On the other hand, the persona shows calculated actions due to the need to conform to other people's expectations.

sapagitan ng suklay at lipstick. (Mabanglo, 396)

The persona can be attributed as someone who is expected to fix and to arrange his/her face, hair, dress, and uniform before going to work. This is a common situation to 
Litinfinite Journal

ISSN: 2582-0400 [Online]

CODEN: LITIBR

Vol-2, Issue-1 ( $2^{\text {nd }}$ July, 2020)

Page No: $11-16$

DOI: 10.47365/litinfinite.2.1.2020.11-16

Section: Article

carry out the persona's image. It correlates with the essay of Tolentino (on Salazar 240) on the malling culture of the Philippines. He contemplated that the mall employees are equally maltreated as the mall-goers, as they are projected as eroticized objects by the capitalists. He also criticized that the employees, through systematic regimentation of their bodies, reveal the necessity in the service economy - young, with a pleasing personality, and is willing to work. Capitalists invest the feminized commodification of the consumer that transposes the factual need of individuals. Thus, this kind of consumption is towards the capitalist idea, and it rather depreciates the recognition making it subjective. Mabanglo's Feminist writing is reinforced.

Leitch describes the belief of Marx in the ideology that "the reality of class struggle from our perception and consciousness; and insofar as working-class people unconsciously absorb bourgeois values, they are unwitting carriers of "false consciousness." (Leitch, 762) Therefore, compliance with the company policy, in this case - the looks, is profoundly invested. The author also insinuates captivity with the line-

\section{Nagkakandadoako ng pinto (Mabanglo, 396)}

The lock and door are used to display the metaphor of imprisonment. This kind of image exhibits oppression to freedom, the persona agonizes in the experience of poverty, since, the preliminary parts of the poem reveals it.

The ideas presented are interested in dealing with dominance and oppression as explained by Marx where he opines that the bourgeois society, capital is independent and has individuality, while the living person is dependent and has no individuality.

Thus, it is not only the bourgeois values that they carry in but also the idea of dependence to the dominant as it pursues hegemony.

\section{The Political Motive}

The political motive is essential in the development, production, projection, promotion, and interpretation of the texts. It indicates the rationale of writing and the motivation of the writer in creating the text. The writer's beliefs, in this case, will obviously arise. Hamadi discusses that it supplements Marxism as it views "literature as historical forces that can be studied by looking at the material conditions in which they are produced" (155). It aids in perceiving the politics of the literature. Paghabol debates:

\section{walangpangalangpagsusuot \\ ng kaninumangdamit, (Mabanglo, 396)}

The lines expound the idea that the persona is part of the workforce and needs to earn; there is a possibility that the persona has multiple jobs. This is significantly possible since the character is struggling financially. 
Litinfinite Journal

ISSN: 2582-0400 [Online]

CODEN: LITIBR

Vol-2, Issue-1 ( $2^{\text {nd }}$ July, 2020)

Page No: $11-16$

DOI: 10.47365/litinfinite.2.1.2020.11-16

Section: Article

Regardless of the situation, the motivation of the persona in working will still be the wage. Any experiences will all reduce to the need to survive, since the need to provide continues. However, there is a possibility that the persona is also constricted with socio-economic exploitation and deprivation that hinders the progress and pursues dehumanization.

\author{
isip at damdaminghumahabol ng dyip \\ sakanto ng mgasaglit, \\ katawangtumatawadsapresyo \\ ng mgaminuto - (Mabanglo, 397)
}

These lines advance the idea that the text is for those who are struggling in poverty. There is a comprehensible motive of the author to show that these are not focused on the physical pain and fatigue alone, but, Paghabol also depicted the emotional exhaustion of the persona in realizing the fate.

\author{
sapagitan ng mgatambutso, \\ walangkasariansi Bernardo Carpio. (Mabanglo, 397)
}

Mabanglo made it clear that it is not limited to any specific gender, preference, or orientation. The Bernardo Carpio - a local fictional character - archetype shows that the persona embodies those people who also experienced exploitation in work. When it losses its rhythm, the same as the clock, the mechanized persona might similarly lose balance and can cause more problems. The colliding rocks between Carpio contemplate with the difficulties and exploitation experienced by the persona in Paghabol.

As Mabanglo wrote Paghabol ng Dyip, it has provided facets on reading her poesy and proving that her writing is not entirely restricted in feministic views; instead, it explores dimensions of society, culture, ideology, and literature and its criticism.

This critique has made connections from the metaphor of the robotic-like life to the socio-political exploitation and struggles experienced by the poor, and how the capitalists invest on the commodification of people by manipulating the standards of/in/and beauty.

The prevalence of bigger forces can also be anticipated since orchestration to the ideologies of the vulnerable towards the promise of fulfilling the necessity is undeniable. Paghabol revealed the politics of the workforce and service economy and the experience of degradation.

The jeepney symbolizes the chase in the persona's life-traveling, jammed, wedged in heavy traffic, restless, and hardworking.

\title{
Works Cited
}


i. $\quad$ Adesina, Oluwagbemiro. "Marxism and Sam Aihimegbe's Blood in the Creek." CSCanadaStudies in Literature and Language, 15.4(2017): pp.1-10. Web. 6 April 2020. < http://cscanada.net/index.php/sll/article/view/9921/10551>

ii. Althusser, Louis. On the Reproduction of Capitalism: Ideology and Ideological State Apparatuses. New York: Verso Trade, 2014. Print.

iii. Eagleton, Terry. Criticism and Ideology: A Study in Marxist Literary Theory. Brooklyn: Verso, 2006. Print.

iv. Hamadi, Lufti. "The Concept of Ideology in Marxist Literary Criticism." European Scientific Journal, 13.20(2017): pp.154-168. Web. 5 April 2020. 〈http://eujournal.org/index.php/esj/article/view/9653>

v. Hernando, Pauline Mari. "Ang Politika ng Katawan sa Panulaan ni Elynia S. Mabanglo/ The Body Politics in the Poetry of Elynia S. Mabanglo." Malay, 28.1 (2015). Web. 20 July 2020. $<$ https://ejournals.ph/issue.php?id=744>

vi. Leitch, Vincent B, and William E Cain. The Norton Anthology of Theory and Criticism. 2nd ed. New York: W. W. Norton \& Company, 2010. Print.

vii. Mabanglo, Ruth Elynia. "Paghabol Ng Dyip and Regla Sa Buwan Ng Hunyo." Philippine Studies, 33.3(1985): pp.396-398.Philippine Studies Historical \& Ethnographic Viewpoints. Web. 9 April 2020. < http://www.philippinestudies.net/ojs/index.php/ps/article/view/3580>

viii. $\quad$ Marx, Karl. Communist Manifesto. London: Pluto Press, 1996.

ix. Morales, Deidre. "Sa Umaga at sa Gabi: Ang SalungatansaPaglikha ng Babaeng Persona

$x$. Panda, Aditya. "Marxist Approach to Literature: An Introduction." Journal of Teaching and Research in English Literature, 6.3 (2015). Web. 6 April 2020. < https://papers.ssrn.com/sol3/papers.cfm?abstract id=2604888>

xi. sa "Paghabol ng Dyip" ni Ruth ElyniaMabanglo at "Time In." Undergraduate and Graduate Conference on Literary, Cultural, and Performance Studies. 7 Mar 2020. De La Salle University - Manila. Paper Presentation

xii. Tadiar, Neferti X. Things Fall Away: Philippine Historical Experience and the Makings of Globalization. Durham: Duke UP, 2009. Print.

xiii. Tolentino, Rolando. "Malling, Subcontracting, at SerbisyongEkonomiya Sa SM." Edited by Joseph Salazar and Mark Benedict Lim. Babasahinsa KulturalnaMalayunin Komunikasyon. KomisyonsaWikang Filipino and Filipinas Institute of Translation, 2017. 